\title{
Manichaean Imagery of Christ as God's Right Hand
}

\author{
Johannes van Oort ${ }^{*}$ \\ University of Pretoria \\ j.van.oort@planet.nl
}

\begin{abstract}
The article examines the conspicuous references to God's 'Right Hand' in Manichaeism by analysing texts from both Western and Eastern sources. The analysed texts prove that the eye-catching imagery (directly or indirectly) refers to Christ. Perhaps this imagery of Christ as God's Right Hand also had its place in Manichaean art. The article aims to function as background for a subsequent study of Augustine's portrayal of Christ as manus or dextera Dei in his Confessions.
\end{abstract}

\section{Keywords}

Manichaeism - Christology - God's Right Hand - imagery - metaphorical language - Manichaean Christian art

\section{Introduction}

The past years have seen an increasing number of studies on Christ in Manichaeism. ${ }^{1}$ One striking aspect, however, is still to be explored, sc. the

\footnotetext{
* I would like to acknowledge Jason BeDuhn, Zsuzsanna Gulácsi and Anne-Maré Kotzé for their attentive reading of an earlier version of this article. The study was completed with the support of the National Research Foundation (NRF) in South Africa.

${ }^{1}$ Apart from overviews in general publications on Manichaeism, the main topical studies include: I. Gardner, 'The Docetic Jesus-Some Interconnections Between Marcionism, Manichaeism and Mandaeism', in: idem (ed.), Coptic Theological Papyri II: Edition, Commentary, Translation, Wien: In Kommission bei Verlag Brüder Hollinek 1988, 57-85; N.A. Pedersen, 'Early Manichaean Christology, Primarily in Western Sources', in: P. Bryder (ed.), Manichaean Studies, Lund: Plus Ultra 1988, 157-190; Gardner, 'The Manichaean Account of Jesus and the Passion of the Living Soul', in: A. Van Tongerloo \& S. Giversen (eds.), Manichaica Selecta. Studies presented to Professor Julien Ries on the occasion of his seventieth birthday, Louvain: IAMS-BCMS-CHR 1991 (Diffusion: Brepols, Turnhout), 71-86; S.G. Richter, 'Christology in the Coptic Manichaean Sources', BSAC 35 (1996) 117-128; idem, 'Bemerkungen zu verschiedenen "Jesus-Figuren” im Manichäismus', in: J. van Oort a.o. (eds.), Augustine and Manichaeism in the Latin West, LeidenBoston-Köln: Brill 2001 (repr. Leiden-Boston: Brill 2012), 174-184; J. BeDuhn, 'The Manichaean Jesus', in: O. Hammer (ed.), Alternative Christs, Cambridge: CUP 2009, 51-70. The most comprehensive and authoritative study remains that of E. Rose, Die manichäische Christologie,
} 
metaphor of Christ as God's (Right) Hand. The present article aims at filling this gap, both by analysing the relevant Manichaean texts and looking for its background in other early Christian testimonies. A next article will investigate why and to what extent the metaphor played a role in Augustine's Confessions.

\section{A. Testimonies from Manichaean Literature}

\section{Latin Testimonies}

In view of the available data and their direct relation to Mani's own scriptures, it seems appropriate to start our overview with those texts on 'God's Hand' which have survived for posterity in Latin.

\section{i. Mani's Epistula fundamenti}

The church father Augustine turns out to be the only source that hands down (in a polemical context, which turns out to be important for our understanding) the following fragment from Mani's 'Fundamental Letter' in a Latin translation:

Pax, inquit, dei inuisibilis et ueritatis notitia sit cum fratribus sanctis et carissimis, qui mandatis caelestibus credunt pariter atque deseruiunt. ita sit, ut dicit. nam et ista benigna et acceptissima optatio est. tantum meminerimus haec et a bonis doctoribus et a deceptoribus dici posse. itaque si nulla nisi talia diceret, omnibus legendum et amplectendum esse concederem. nec illa, quae adhuc sequuntur, inprobauerim; adiungit enim: sed et dextera luminis tueatur et eripiat uos ab omni incursione maligna et a laqueis mundi. et omnino quidquid in huius epistolae principio scriptum est, donec ueniatur ad causam, nolo reprehendere ... (c. ep. fund. 11; CSEL 25,207)

Mani says: "May the peace of the invisible God and the knowledge of the truth be with the holy and most dear brothers, who believe and likewise zealously observe the heavenly commandments'. May that be the case indeed! For this too is a good and most acceptable wish. Only we should bear in mind that this can be spoken by good teachers and by deceivers. Therefore, if he did say only such things, I would concede that everyone should read the letter and embrace it. Nor would I disprove of the words that follow after this. For he adds: 'And may indeed the Right Hand of the Light protect and rescue you from every evil incursion and from the snares of the world'. In fact, I do not find fault with anything that is written at the beginning of this epistle until it comes to its main subject matter.

Wiesbaden: Harrassowitz 1979. This 1937 Marburg dissertation under the guidance of H.H. Schaeder, R. Bultmann, a.o. first saw the light in an updated form forty-two years later. 
Here, in his work Against Mani's Fundamental Letter, Augustine quotes two full sentences from Mani's Epistula and also states that one succeeds the other ('adiungit enim'). This is corroborated by Augustine's later quotation of virtually the same words ${ }^{2}$ in his Against Felix the Manichaean. There we also find their continuation:

pietas uero spiritus sancti intima pectoris uestri adaperiat, ut ipsis oculis uideatis uestras animas ... (c. Fel. 1,16; CSEL 25,819)

May indeed the compassion of the Holy Spirit fully open the inmost parts of your heart so that you may see your souls with your own eyes ...

From the context of the quotes in c. ep. fund. and $c$. Fel. we may deduce that, after its opening lines, ${ }^{3}$ the following sentences of Mani's Epistula read as given above. ${ }^{4}$ These sentences will have had extra weight both for the original writer and his readers. One easily discerns its 'triadic' or even 'trinitarian' ${ }^{5}$ composition: Mani first speaks of 'the invisible God', after that of 'the Right Hand of the Light', and subsequently of 'the Holy Spirit'. As will become clear from many other Manichaean texts, there can be no doubt that the metaphor of 'the Right Hand of the Light' (i.e., of God the Father) is a metaphor for Christ. In a similar manner as Augustine will do in his Confessions, already Mani stresses the role of Christ as the one who protects ${ }^{6}$ and rescues ('tueatur et eripiat').

It may be noted that Augustine emphatically remarks in his c. ep. fund. (as quoted above: 'nolo reprehendere') and also in his dispute with Felix after the first part of Mani's Epistula had been read aloud, that in Mani's statements—apart from his claim to be Christ's apostle- he does not find anything evil ('nibil mali': c. Fel. 1,16; CSEL 25,819). This implies that, in his contacts with the Manichaeans, Augustine may make use of the same metaphor of God's Right Hand, and that his former coreligionists will fully understand and even appreciate this metaphor. In other

\footnotetext{
${ }^{2} \mathrm{~J}$. Zycha in his edition of $c$. Fel. has nobis for dei, suis for sanctis and laqueo for laqueis (CSEL $25,819)$.

${ }^{3}$ C. ep. fund. 5 (CSEL 25,197): 'certe sic incipit: Manichaeus apostolus Iesu Christi prouidentia dei patris. haec sunt salubria uerba de perenni ac uiuo fonte. (c. ep. fund.11; CSEL 25,206:) quae qui audierit et isdem primum crediderit, deinde, quae insinuant, custodierit, numquam erit morti obnoxius, uerum aeterna et gloriosa uita fruetur. nam profecto beatus est iudicandus, qui hac diuina instructus cognitione fuerit, per quam liberatus in sempiterna uita permanebit'. Cf. c. Fel. 2,1 (CSEL 25,801), with the minor differences of 'ex' for 'de' ('ex/de perenni ... fonte'), 'insinuata sunt' for 'insinuant' and 'iisdem' in stead of 'isdem'.

${ }^{4}$ They are immediately followed by Mani's version of 'the birth of Adam and Eve' (c. ep. fund. 12; CSEL 25,208: 'natiuitas Adae et Euae'), after which he recounts his creation story, in which his theory of two eternal substances is first expounded (c. ep. fund. 15ff.).

${ }^{5}$ Cf. e.g. Rose, Manichäische Christologie (n. 1), 158-161.

${ }^{6}$ Or: 'looks at you with care' (cf. Vergilius' idiom).
} 
words, already as a Manichaean, who listened to the readings of Mani's Epistula, and strongly makes the impression of knowing its contents by heart, ${ }^{8}$ Hippo's future bishop became acquainted with the image of Christ as God's Hand. When he wrote his refutation of Mani's Epistula at the end of 396 or the beginning of 397 (i.e., about the same time he most likely started his conf.), he appreciated the metaphor as it was used by Mani himself. The same is evident from his dispute with Felix in December 404.

\section{ii. Secundinus'Epistula ad Augustinum}

It was (in all probability) sometime after this period that Augustine received a letter from the Roman Manichaean Secundinus. ' This letter belongs to the very few original Manichaean texts which came down to us in Latin. It seems to have been written after Secundinus had read (parts of) Augustine's conf. Secundinus opens his letter by speaking of his gratitude to 'the ineffable and most holy majesty' (Habeo et ago gratias ineffabili ac sacratissimae maiestati), 'his first born, the king of all lights Jesus Christ' (eiusque primogenito omnium luminum regi Iesu Christo), and the Holy Spirit (habeo gratias et subplex sancto refero spiritui). He then remarks:

nec mirum; sunt enim et ad omnia bona praestanda et ad omnia mala arcenda satis aptissimi et potentissimi, quibus tuam beneuolentiam suis defendant propugnaculis eripiantque ab illo malo, non quod nihil est aut quod factione passioneque mortalium gignitur, sed quod paratum est, ut ueniat. uae autem illi, qui se eidem praebuerit occasionem. (CSEL 25,893)

Nor is it surprising, for they are most apt and powerful both to provide all good things and to ward off all evils, from which may they protect your goodness with their defences, and rescue it from that evil — not the one which is nothing or which is produced by the strife and passion of mortals, but the one which has been made ready to come. But woe to him who offers himself to it as an occasion.

\footnotetext{
${ }^{7}$ E.g. c. ep. Man. 5.

${ }^{8}$ As in his debate with Fortunatus in 392; cf. J. van Oort, 'Heeding and Hiding their particular Knowledge? An Analysis of Augustine's Dispute with Fortunatus', in: T. Fuhrer (ed.), Die christlich-philosophischen Diskurse der Spätantike, Stuttgart: Steiner Verlag 2008, 113-121. In retr. 2,2,1, Augustine remarks that he has an annotated copy of Mani's Epistula at his disposal, perhaps the same copy which played a remarkable role in his dispute with Felix in 404 (cf. c. Fel. 1,1: 'Et cum Augustinus episcopus epistulam Manichaei, quam Fundamenti appellant, protulisset, dixit: ...') and already earlier (c. 396/7) in his c. ep. Man.

${ }^{9}$ As a rule, the letter is dated 'sometime after 404', although some researchers remain undecided and date it to a time span running from 399 to 404/5 or even 411. Cf. J. van Oort, 'Secundini Manichaei Epistula: Roman Manichaean Biblical Argument in the Age of Augustine', in: Van Oort a.o. (eds.), Augustine and Manichaeism in the Latin West (n. 1), 161-173
} 
It is conspicuous that, according to Secundinus, the triadic Godhead ('they') both protects (defendant, cf. arcenda) and rescues (eripiant). In other words, the function which Mani in his Epistula fundamenti ascribes to Christ is assigned to the Manichaean Trinity. ${ }^{10}$

The sentence immediately following is also important in this context, because here already Secundinus stresses the central role of Christ:

nam dignus es, qui ab iisdem talia munera consequaris iidemque ueritatis tuae nutritores efficiantur. uere lucerna, quam in cordis tui candelabro dextera posuit ueritatis ... (CSEL 25,893)

For you (Augustine) are worthy to obtain such gifts from them and that they should be made nurturers of your truth, you who are really a lamp which the Right Hand of the truth has placed in the lampstand of your heart ...

The imagery of the lamp and the lampstand reminds one of Mt. $5: 15,{ }^{11}$ a text from the Gospel with which Secundinus shows himself familiar in the course of his letter, as he also shows himself well acquainted with the Pauline writings and many other biblical texts. ${ }^{12}$ Without a doubt 'the Right Hand' is a metaphor for Christ, this time termed 'the Right Hand of the Truth', i.e. of the first person in the Manichaean Trinity, who according to Mani's Gospel is 'the Father of Truth'. ${ }^{13}$ As Secundinus time and again states in his letter, 'truth' is the kernel of his Manichaean belief, and it is this truth to which he urgently recalls his former Manichaean fellow.

By designating Christ as 'the Right Hand of Truth', Secundinus places him at the centre of his Christian belief. ${ }^{14}$ It is not only a notable fact that he

\footnotetext{
${ }^{10}$ Which is easily understood from the standpoint of the Manichaeans' true or alleged 'modalism' (cf. e.g. Augustine, c. Faust. 20,11-12).

${ }^{11}$ But, perhaps, also suggests that the formerly zealous Manichaean Augustine was some sort of Mani redivivus. With regard to Mani, the Coptic Manichaean Psalmbook (ed., transl. Allberry

[below n. 15], 23 line 7-8) states: 'He gave light with his Light to our lamps. Put oil into them by your faith.' As the same Psalmbook frequently testifies (e.g. 25,15-17; 37,30-31; 154,1-9; 161,1920; 170,23-24; etc.), the parable of the wise and foolish virgins from Mt. 25 was well known among the Manichaeans.

${ }^{12}$ Cf. van Oort, 'Secundi Manichaei Epistula' (n. 9).

${ }^{13}$ See the pro-oemium of Mani's Gospel as quoted on p. 66 of the CMC (see e.g. L. Koenen \&

C. Römer, eds., Der Kölner Mani-Kodex. Abbildungen und diplomatischer Text, Bonn: Rudolph Habelt 1985, 130).

${ }^{14}$ See e.g. his reproaches to Augustine in the course of his letter: 'nusquam nero conperi christianum' (CSEL 25,895); 'si uis Christo placere' (CSEL 25,899); 'desine, quaeso, utero claudere Christum, ne ipse rursus utero concludaris' (CSEL 25,899); 'noli esse erroris lancea, qua latus percutitur saluatoris' (CSEL 25,895); his positive speaking in regard to Paul: 'ut Christum lucrifaceret' (CSEL 25,899); his wording 'ad quod dominus noster [= Christ] inuitat (CSEL 25,894); 'tunc a domino pelletur ex conuinio nuptiarum nigrarum causa nestium' (CSEL 25,894); etc.
} 
communicates this metaphor at the very beginning of his letter, but also that he seems to have reason to expect Augustine's full understanding in this regard. While calling to mind Jesus' words according to the Gospel of Matthew, he even goes so far as to see Augustine as a real and true (Manichaean) lamp, set in place by God's Right Hand, Christ. It is also striking that, in his long answer to Secundinus, Augustine never opposes either his being a true lamp of Christ or (most important in this context) the metaphor of Christ as God's Right Hand.

\section{Coptic Testimonies}

A whole range of texts testifying to the Manichaean image of Christ as God's Right Hand can be found in the Coptic Manichaean literature. Many of these texts were discovered in Egypt at the end of the 1920s; their edition started soon afterwards, but is still unfinished. ${ }^{15}$ It would exceed the present scope to quote in full and comment on all the relevant testimonies from these Coptic texts; ${ }^{16}$ here, only a few of the most characteristic ones may be discussed.

\section{iii. Testimonies from the Manichaean Psalmbook}

As regards Christ at God's right hand, one of the 'Psalms of Heracleides' in the Manichaean Psalmbook states that 'He sat on the right hand of his Father among the living' ${ }^{17}$ In another Psalm of the same series, the image of 'the Right Hand' is

\footnotetext{
${ }^{15}$ See e.g. H.J. Polotsky (ed., tr.), Manichäische Homilien. Manichäische Handschriften der Sammlung A. Chester Beatty, Stuttgart: Kohlhammer 1934; C.R.C. Allberry (ed., tr.), A Manichaean Psalm-Book, Part II, Manichaean Manuscripts of the Chester Beatty Collection II, Stuttgart: Kohlhammer 1938. H.J. Polotsky \& A. Böhlig (eds., tr.), Kephalaia, Band I,1, Manichäische Handschriften der Staatlichen Museen Berlin, Stuttgart: Kohlhammer 1940; A. Böhlig (ed., tr.), Kephalaia, Band I, 2, Lieferung 11/12, Manichäische Handschriften der Staatlichen Museen Berlin, Stuttgart: Kohlhammer 1966; I. Gardner (tr.), The Kephalaia of the Teacher. The Edited Coptic Manichaean Texts in Translation with Commentary, Leiden-New York-Köln: E.J. Brill 1995 (repr. Leiden-Boston: Brill 2016); G. Wurst (ed., tr.), The Manichaean Coptic Papyri in the Chester Beatty Library: Psalm Book, Part. II, Fasc. 1, Die Bêma-Psalmen (CFM, Series Coptica I, Pars II,1), Turnhout: Brepols 1996; S.G. Richter (ed., tr.), The Manichaean Coptic Papyri in the Chester Beatty Library: Psalm Book, Part. II, Fasc. 2, Die Herakleides-Psalmen (CFM, Series Coptica I, Pars II,2), Turnhout: Brepols 1998; W.-P. Funk (ed., tr.), Kephalaia, Band I, 2, Lieferung 13-14/15-16, Manichäische Handschriften der Staatlichen Museen Berlin, Stuttgart: Kohlhammer 1999/2000; N.A. Pedersen, The Manichaean Coptic Papyri in the Chester Beatty Library: Manichaean Homilies (CFM, Series Coptica II), Turnhout: Brepols 2006. The first ever edition of the Dublin Kephalaia by I. Gardner, J.D. BeDuhn and P. Dilley is scheduled to appear from 2018 onwards.

${ }^{16}$ To which may be added those discovered at Kellis in the Dakleh Oasis; cf. n. 56 below.

${ }^{17}$ Allberry, Manichaean Psalm-Book, 196 line 32; cf. Richter, Herakleides-Psalmen, 86-87 and S. Richter, Exegetisch-literarkritische Untersuchungen von Herakleidespsalmen des koptisch-manichäischen Psalmenbuches, Altenberge: Oros Verlag 1994, 273 and 306: 'Er setzte sich zur Rechten seines
} 
evoked in connection with the Mind ${ }^{18}$ which is a manifestation of Christ. ${ }^{19}$ Most common and most important are those Psalms in which Christ is implored to stretch out his own right hand in order to rescue. In a 'Psalm to Jesus' it runs: 'To me stretch out thy right hand; come, I beseech thee, draw me up out of Hades of the dead'; ${ }^{20}$ in another 'Psalm to Jesus' it is stated: 'stretch out thy right hand to me that(?) I may leave the things of the body behind'; ${ }^{21}$ again in another Psalm of the same series it runs: 'Jesus my helper, give me thy right hand .... ${ }^{22}$ Also, at another place one reads: 'Jesus, my God, I implore thee, give me thy right hand, do not desert me'. ${ }^{23}$

Furthermore, we hear in the Psalms that the right hand of the Mind, who is called 'Father', ${ }^{24}$ protects: 'I have received thy words, o my Father: stretch out to me now thy right hand that the seven demons that are before me may see and go far away from me'. ${ }^{25}$ The same we see in one of the Psalms of the Wanderers: the Mind (i.e., the first emanation called forth by Jesus the Splendour) is addressed as: O Mind, '(b)ecause of thy strong protection, lo, my diseases passed far from me. Lo, joy has overtaken me through thy right hand that came to me'. ${ }^{26}$

The last quoted sentences already touch upon another theme which is dear to Manichaean doctrine and piety: Jesus, who stretches out his right hand, is also the physician. This notion resounds in many psalms, for instance in the Psalms of the Bema: 'Jesus, the Physician of the wounded, the Redeemer of the living souls'; ${ }^{27}$ 'He (i.e., your brother) has need of the physician (i.e., Jesus) who goes ... and bears the burning of the medicines, that he may see the light. The physician of souls, he

Vaters / zwischen die Lebendigen'. 'The living' are those who are released by Christ from the underworld and its death; cf. Psalm-Book 196, 1. 16 and 21.--It may be added here that in Manichaean mythology this sitting of Christ at God's right hand is foreshadowed by First Man's sitting at God's right hand; see e.g. Kephalaia (ed. Polotsky) 40, 1. 11-14.

${ }^{18}$ Allberry, Psalm-Book, 108 1. 22-23: 'Come (?) ... right hand wherein there is no envy'; cf. Richter, Herakleides-Psalmen, 45: ' [ - - ] die Rechte ist es in der kein Neid ist'.

${ }^{19}$ See e.g. Allberry, Psalm-Book, 166 1. 35: Jesus is the 'Father of the Mind of Light'. On the complicated concept of the Manichaean 'Mind' or 'Intellect', see e.g. A. Van Tongerloo \& J. van Oort (eds.), The Manichaean NOY2, Lovanii: IAMS-BCMS-CHR 1995 (Diffusion: Brepols, Turnhout).

${ }^{20}$ Allberry, 67 1. 14-16.

${ }^{21}$ Allberry, 69 1. 6-7.

${ }^{22}$ Allberry, 94 1. 1. Cf. Psalms of Heracleides CCLXXX (Allberry, 101 1. 7): '... thy [= Lord Christ's] wise right hand'.

${ }^{23}$ Allberry, 112 1. 26-27.

${ }^{24}$ For other texts in which Christ is called 'Father', see e.g. Waldschmidt \& Lentz, Stellung Jesu (below, n. 57), 36-37 in particular.

${ }^{25}$ Allberry, 108 1. 17-19. Cf. for Christ's Hand protecting against the demons the quote from the Chinese Hymnscroll 63 c-d below.

${ }^{26}$ Allberry, 153 1. 3-4.

${ }^{27}$ Allberry, 2 1. 24-25. 
is the Light-Mind'. ${ }^{28}$ In a 'Psalm to Jesus' it goes: 'He that is wounded and desires healing, let him come to the physician'. ${ }^{29}$ The same theme is also heard in other psalms: 'Be not far from me, o Physician that hast the medicines of life .... Behold, I am watching for thee, I ... to receive thy cures. For thou art my Saviour that wast appointed to save me'; 'The Son of the living God, the physician of souls ...; ; ' $\mathrm{I}$ heard the cry of a physician, the cry of a[n] exorcist coming (?) to [me. I] heard the cry of a physician healing the poor ones (?). .... O physician (?), heal me, loose my ..... ${ }^{32}$ As it is said of Jesus, so it is said of Mani: God, the Father of Greatness ${ }^{33}$ 'anointed him in his power' and 'appointed him to three powers, to tribulation, to a right hand, to bliss' and 'He gave into his hands the medicine of life that he might heal the wounded'. ${ }^{34}$ Another Psalm of the Bema elaborates on Mani's work as a doctor who has his medicaments and instruments: 'Lo, the great physician has come'. ${ }^{35}$

Already these quotes from the Psalmbook testify to the central place of Jesus or Christ ${ }^{36}$ in the piety and myth of the Manichaeans. Jesus is not only described as sitting at the Father's Right Hand, he also is the one who stretches out his Right Hand in order to rescue and protect. This saving and protecting Jesus is often hailed as the Physician. In Jesus' wake-as the final manifestation of the Nous, who in the course of the centuries sent out his apostles of truth- Mani is also invoked as 'a right hand' and 'the great physician'.

\section{iv. Testimonies from the Manichaean Kephalaia}

The Coptic Manichaean Kephalaia are discourses ascribed to Mani. ${ }^{37}$ They provide, through more or less systematic description, explanations of certain aspects of the Manichaean myth and rites. Most relevant in this context is Kephalaion IX, i.e. Mani's long 'Explanation of the Peace, what it is; the Ri[gh]t Hand; the Kiss; the Salutation'. ${ }^{38}$ Several years ago, Henri-Charles Puech sought to unlock the main

\footnotetext{
${ }^{28}$ Allberry, 40 1. 11-13.

${ }^{29}$ Allberry, 57 1. 21-22.

${ }^{30}$ Allberry, $1521.22 \& 27$.

${ }^{31}$ Allberry, 193 1. 13; cf. Richter, 74-75.

${ }^{32}$ Allberry, $2201.26-28 \& 31$.

${ }^{33}$ Cf. Wurst, Bêmafest, 194 for reconstruction of Allberry, 221.31 and 115-120 for elucidating commentary; cf. Wurst, Bêma-Psalmen (n. 15), 64-65.

${ }^{34}$ Cf. Allberry, 23 1. 2-7; cf. Wurst, Bêma-Psalmen, 64-65.

${ }^{35}$ Allberry, 46 1. 1ff. - 47,10; cf. Wurst, Bêma-Psalmen, 112-115.

${ }^{36}$ In essence, both names designate the same; cf. e.g. Rose, Christologie (n. 1), 60 et al..

${ }^{37}$ For the main editions and translations, see n. 15 above.

${ }^{38}$ Although 'the laying on of the hand' (cheirotonia) is not mentioned in the Kephalaion's title, it is discussed several times in Mani's explanation as the fifth 'mystery' or 'sign'. It may be noted that in the following lines I always speak of 'the laying on of the hand' and do not use the common
} 
part of this Kephalaion in a long course of pioneering lectures published in the series Annuaire du College de France. ${ }^{39}$ The following overview is primarily based upon his still valuable analysis.

The Kephalaion starts with the question of Mani's disciples regarding the origin of the ritual acts (i.e., the greeting with 'the peace', 'the [reaching of the] right hand', 'the kiss', 'the salutation' and 'the laying on of the hand') which occur in human society. ${ }^{40}$ Mani explains that these 'five signs' are re-enactments of divine archetypes: all have been prefigured by the 'mystery of the First Man'. When he descended into the abyss, the gods and the angels of light gave him 'the first peace'; 'the first right hand is the one that the Mother of Life gave to the First Man when he comes out to the contest'; 'the first kiss is the one with which the Moth[er] of Life embraced the First Man'; 'the first salutation' is 'the salutation with which the First Man made obeisance' to the Father; 'the first laying on of the hand' he then received from 'the Mother of Life'. Subsequently, when he ascended, he received the (second) 'peace' from the Father; 'the second right hand' from the Living Spirit; 'the second kiss' from 'the [Father o]f Life and the Mother of the living', after which followed '[the] second [s]alutation with which the First Man made obeisance' and, finally, 'the second laying on of the hand (cheirotonia) ... when the Living Spirit brought the First Man upward from the war. ${ }^{41}$ The Kephalaion then contains a passage which is of special relevance to our subject:

He (i.e., the Living Spirit) brought him upward, he gave him ease in the great aeons of light, which belong to the household of his people. He set [him] firmly before the Father, the Lord of the totality. Now, when he went up before the great Father of the lights, a voice came forth to him from the heights, saying: Make my son, my first-born, to sit at my right hand side, until I set all his enemies for a footstool under his feet. He received this great laying on of the hand (cheirotonia) that he may become leader of his brethren in the new aeon. ${ }^{42}$

Of course, the words spoken by 'a voice ... from the heights' remind us of Mark 12:36 and Matthew 22:44 and, via these New Testament texts, of Psalm 110 (LXX 109):1. The Manichaean First (or: Primal) Man is a prototype of Christ, while his saving act is a prototype of Christ's saving act. This last aspect is also envisioned in

English terminological wording 'laying on of hands': from Keph. IX it is completely clear that we are dealing here with the laying on of one (i.e., without a doubt according to Manichaean thinking, the right) hand. I therefore do not follow Gardner in his translation of the term.

${ }^{39}$ See ACF 1965-1966; 1966-1967; 1967-1968; 1968-1969 (summary); 1969-1970; 1970-1971, reprinted in H.-C. Puech, Sur le manichéisme et autres essais, Paris: Flammarion 1979, 347-389. Cf. e.g. Puech, 'Le manichéisme', in: idem (éd.), Histoire des Religions, II, Paris: Gallimard 1972, 620625.

${ }^{40}$ Polotsky (ed.), Kephalaia, 37,29-38,4.

${ }^{41}$ Polotsky (ed.), Kephalaia, 38,4-40,7; transl. Gardner, Kephalaia, 43-45.

${ }^{42}$ Polotsky (ed.), Kephalaia, 38,4-40,7; transl. Gardner, Kephalaia, 43-45. 
the next Coptic sentence: as it was the case with Christ (cf. e.g. Hebr. 2:10; 12:2), so already Primal Man became the 'leader (archègos) of his brethren'.

For Mani and his followers, the ritual acts in human society are re-enactments of what happened to Primal Man, who is a proto-type of Christ. However, the above explanation is not all that Mani has to say on the five 'mysteries' or 'signs'. According to Kephalaion IX, he continues his teaching by showing that it is through these five 'types' or 'marks' that his church is still being constituted:

The Light Mind al[so], who co[mes] to the world, shall come with these several mark[s]. With these five lessons he shall choose his church. First, before everything else, he chooses his church with peace. And he gives the peace first to mankind; so that the person receives the peace, and becomes a child of peace. Afterwards he is elected to the faith. Now, when he may receive the peace, he shall receive [the rig]ht hand and count to the right hand. Then, whe[n he receives] the right hand, the Light Mind s[h]all draw him to him, and cause [him] to app[roach the ch] urch. With the right hand he receives the $\mathrm{k}$ [iss of lo]ve and becomes a child of the c[hurch ...]. With the kiss he shall receive salutation, and make obeisance to the God of truth. Also, he makes obeisance to the holy church [...] When they will receive the peace and the right hand, the kiss and the salutation, the last of these things shall be bequeathed upon them from the right hand of charity. They too [receive] the laying on of the hand, which will be bequeathed upon them. And they are conformed and built up in the truth, and made strong in it for ever. They shall come to the Light Mind with these good signs: and become fulfilled people. They make obeisance and [give] glory to the God of truth'. ${ }^{43}$

At first sight, the Kephalaion does not speak of Primal Man/Christ as being himself God's (Right) Hand, nor that He is the one who reaches his (Right) Hand in order to save or protect. It is 'the Mother of Life' who gave both 'the first right hand' and 'the first laying on of the hand' while-in the schematic-scholastic overview of Kephalaion IX - it is 'the Living Spirit' who acts in case of 'the second right hand' and 'the second laying on of the hand'. With regard to the Manichaean church's rites, it is the Light-Mind or Nous who is the acting divine figure.

As already suggested by Puech, ${ }^{44}$ however, this representation would be incomplete. In all these acting figures of the Manichaean myth we should see prototypes of the salvation act which finds its essential expression in the manyfaceted Manichaean figure of Jesus. ${ }^{45}$ The story of First or Primal Man is prototypical of what happened to Christ, in the same way as the ritual acts performed in the Manichaean church by the Light-Nous recall Christ's saving acts.

\footnotetext{
${ }^{43}$ Polotsky, 40,24-41,10; Gardner, 45-46. It does not seem necessary to quote or discuss here either the following (rather defective) passage on the role of the five 'signs' in the Manichaean's death and departure out of this life (cf. Polotsky, 41,11-25), or the Kephalaion's concluding summary and injunction (41,26-42,23).

${ }^{44}$ E.g. Sur le manichéisme, 373.

${ }^{45}$ As has been made abundantly clear by Rose, passim.
} 
According to excerpts from Mani's writings handed down by Theodore bar Kōnai (c. 790), it was already 'the radiant Jesus' who appeared to Adam and saved him. ${ }^{46}$ Besides, there are several cases in the Manichaean writings in which Primal Man stands for Jesus, and vice versa. ${ }^{47}$ Very much the same goes for the Light-Nous, who according to Manichaean doctrine is a direct emanation of the heavenly 'Jesus the Splendour'. ${ }^{48}$ The fact that the Manichaeans identified themselves as 'the children of the Right Hand ${ }^{49}$ will not only be due to the fact that First Man is called to sit at God's Right Hand, but also because in the Last Judgement (cf. Mt. 25, already well known to Mani ${ }^{50}$ ) the Manichaean Jesus places the Elect at his right hand. ${ }^{51}$ Time and again, the saving acts via the right hand of the just mentioned mythical figures - all of whom represent Jesus - are repeated in the Manichaean church.

As indicated by Puech, these rites - in more contemporary vocabulary: saying 'peace' when one meets somebody; the subsequent extension and clasp of the right hands or iunctio dextrarum; the brotherly kiss; the uttering of words of 'veneration' or 'adoration' of the person one meets; and finally the laying on of the right hand-were performed both in case of the admission of the Auditors ${ }^{52}$ and in case of the installation in the higher ranks, such as the one of the Elect. The final act in this series, its achievement and apogee, ${ }^{53}$ was undoubtedly termed 'the

${ }^{46}$ Cf. the translated extracts from Theodor's Liber scholiorum in A. Adam (ed.), Texte qum Manichäismus, Berlin: De Gruyter 1969², 22: 'Und er weckte ihn auf, hielt ihn (fest) und schüttelte ihn'; 'Er richtete ihn auf ...'.

${ }^{47}$ Cf. Puech, Sur le manichéisme, e.g. 46; see already F.C. Baur, Das manichäische Religionssystem nach den Quellen neu untersucht und entwickelt, Tübingen: C.F. Osiander 1831 (repr. Göttingen: Vandenhoeck \& Ruprecht 1928; repr. Hildesheim-New York: Georg Olms 1973), 209-210; Polotsky, 'Manichäismus', PRE Suppl. Bd. VI, Stuttgart: Metzler 1935, 258.

${ }^{48}$ See e.g. Kephalaion VII in Polotsky (ed.), Kephalaia, 34-36.

${ }^{49}$ See e.g. Puech, Sur le manichéisme, 372 with reference to a passage from Mani’s Shäbubragàn quoted by the Muslim writer al-Murtadā, and a number of text fragments from Turfan (M 4; M 801; M 36); cf. e.g. A.V.W. Jackson, Researches in Manichaeism with Special Reference to the Turfan Fragments, New York: Columbia University Press 1932 (repr. New York: AMS Press 1965), 265 n. 25.

${ }^{50}$ See e.g. M. Hutter, 'Mt 25:31-46 in der Deutung Manis', NT 33 (1991) 276-282.

${ }^{51}$ Cf. Puech, Sur le manicheisme, 372, with further references; cf. e.g. Jackson, Researches, 264 n. 25.

${ }^{52}$ Cf. Puech, Sur le manichéisme, e.g. 354, 360 and 374. In Keph. XC (ed. Böhlig, 226,8-10), it is stated explicitly that an Auditor 'received the right hand of [p]eace and trusted and became established in the rank of the true catechumenate' (tr. Gardner, 234) and in Keph. XCI (ed. Böhlig, 232,5-7) it runs with regard to the 'catechumen': 'he has received the right hand of pea[ce] from the Light Mind who dwells in the holy church' (tr. Gardner, 238).

${ }^{53}$ Cf. Puech, 354: 'cette 'Droite' est imposé 'en conclusion' (thaê) des quatre autres rituelles (le salut du paix, la poignée de main, le baiser, la 'vénération' ou 'adoration'), ce qui porte à imaginer que le kheïrotonia devait se situer à la fin d'une cérémonie où elle était précédée par l'accomplissement successif des quatre 'mystères' en question et dont elle constituait l'achèvement aussi bien que l'apogée.' 
Right Hand', in the text quoted above and also elsewhere specified as 'the Right Hand of (the) Grace' or 'of (the) Peace'. ${ }^{54}$

We may be sure that the long-standing auditor Augustine will have been thoroughly acquainted with these and similar rites of the imposition of the right hand.$^{55}$ Furthermore, at the time of his entrance into Mani's Church, he will have undergone this whole ritual, so deeply rooted in Mani's myth, when becoming a 'catechumen'.

\section{Testimonies from other Manichaean Texts}

The overview that we have just given of testimonies from Coptic Manichaean texts $^{56}$ may be sufficient to substantiate two conclusions. The first one is that these texts bear witness to the fact that the figure of the Right Hand was central to Manichaean myth and ritual. The second conclusion is that Jesus is often depicted as the one who is not only at God's Right Hand but also is God's Right Hand and, moreover, stretches out his (Right) Hand in order to save, heal, and protect.

In many Eastern Manichaean documents, pre-eminently those from Turfan and Dunhuang, we find the same. On the basis of Persian, Sogdian, Turkic and, in particular, a selection of Chinese texts from the Manichaean Hymnscroll dated from about $800 \mathrm{CE}$ and kept in London, Ernst Waldschmidt and Wolfgang Lentz provided an impressive documentation of the unique place of Jesus in

\footnotetext{
${ }^{54}$ Kephalaia 41,5 (the translation 'grace' is to be preferred here above Gardner's 'charity'); cf. Polotsky's rendering of 41,5: 'die Rechte der Gnade'. See also in, for instance, Keph. LVIII (Kephalaia, ed. \& transl. A. Böhlig, 148,19-20): 'Rechte[n] des Friedens und der Gnade' and Keph. XC and XCI (ed. \& transl. Böhlig, 226,8: 'Friedensrechte' and 232,5-6: 'Rechte des Friedens'). ${ }^{55}$ See Augustine, ep. 236,2 (CSEL 57,524): 'ipsi auditores ante electos genua figunt, ut eis manus supplicibus inponatur non a solis presbyteris uel episcopis aut diaconis eorum sed a quibuslibet electis'. In this quote, 'inponatur' indicates that only one hand was involved, i.e., considering all other evidence, the right one. Cf. also Augustine, haer. 46,16 (CCL 46,318): '... episcopos autem septuaginta duos, qui ordinantur a magistris, et presbyteros, qui ordinantur ab episcopis indefiniti', where 'ordinantur' seems to imply the laying on of the right hand.-One may agree, then, with M. Klöckener, 'Impositio manus', AL 3 (2004-2010) 560-564, who states (562 n. 1) that Augustine prefers the singular and further remarks: 'Ein Bedeutungsunterschied zwischen singularischem und pluralischem Gebrauch ist nicht zu erkennen'.

${ }^{56}$ It may be supplemented by P. Kell. Gr. 97, a rather recently discovered Manichaean text in Greek from Kellis in the Egyptian Dakhleh Oasis, which on fragment B.I v reads : '... his most right hand was on you'. Cf. I. Gardner, Kellis Literary Texts, 2, Oxford: Oxbow Books 2007, 94110 (text 101; transl. 103; provisional interpretation 109). Mainly due to the fragmentary status of papyrus leaves, the exact meaning of this statement remains unclear. In essence, the same goes for the fragmentary text T.Kell.Copt. 2 (cf. I. Gardner a.o., Kellis Literary Texts, 1, Oxford: Oxbow Books 1996, 8-30), which reads on the very damaged page A 3: 'Straighten thy ri(ght hand (?)' (Coptic text and translation, 11). What appears to be clear, however, is that in both cases we are dealing with fragments of Manichaean psalms.
} 
Manichaeism. ${ }^{57}$ Even though these texts date some four, five or even more centuries after the Coptic ones and show many traces of syncretism (in particular with Zoroastrianism and Buddhism), they nevertheless contain many marks of original Manichaean thinking, while some of them are even said to contain reminiscences of Mani's ipsissima verba ${ }^{58}$ Reading through these texts, one is struck by their portrayal of Jesus as the (Right) Hand who saves, heals and protects. Pivotal testimonies in this context are present in the Hymnscroll as it has first been edited and translated by Waldschmidt and Lentz. ${ }^{59}$ Here it runs, with reference to Jesus:

Großer Heiliger, strecke schnell (deine) mitleidige Hand aus, leg sie auf den lichten Scheitel meines göttlichen Ichs! ${ }^{60}$

O bitte, gewähre (deine) große, mitleidige Hand, nimm an dich meinen dreifältigen reinen tranzendenten Körper, beseitige alle Banden ferner Zeitalter, und wasche allen Schmutz ferner Zeitalter ab. ${ }^{61}$

Gewähre schnell die lichte und mitleidige Hand, auf daß (ich) nicht wieder weg und unter die Klassen der Dämonen geworfen werde. ${ }^{62}$

Waldschmidt and Lentz read these texts as testimonies to the fact that Jesus is the $\delta \varepsilon \xi 1 \alpha \tau o v \varphi \omega \tau o \varsigma$ of which some Western texts speak. ${ }^{63}$ They also refer to a

${ }^{57}$ E. Waldschmidt \& W. Lentz, Die Stellung Jesu im Manichäismus (APAW, Nr. 4, 1926), Berlin: Verlag der Akademie der Wissenschaften in Kommission bei Walter de Gruyter 1926.

${ }^{58}$ Cf. e.g. Waldschmidt \& Lentz, Stellung Jesu, 9.

${ }^{59}$ Later translations are provided by Tsui Chi, 'Mo Ni Chiao Hsia Pu Tsan. The Lower (Second?) Section of the Manichaean Hymns', BSOAS 11 (1943-1946) 174-219 and H. SchmidtGlintzer, Chinesische Manichaica. Mit textkritischen Anmerkungen und einem Glossar, Wiesbaden: Harrassowitz 1987. Reference to the publication of Waldschmidt and Lentz is preferred here, because their translation, provided within the context of their research on the place of Jesus in Manichaeism, appears to be quite literal and still correct.

${ }^{60}$ Hymnscroll 39 a-b; Waldschmidt \& Lentz, Stellung Jesu, 104.

${ }^{61}$ Hymnscroll 55 a-d; Waldschmidt \& Lentz, Stellung Jesu, 107.

${ }^{62}$ Hymnscroll 63 c-d; Waldschmidt \& Lentz, Stellung Jesu, 108.

${ }^{63}$ Waldschmidt \& Lentz, Stellung Jesu, 39, with reference to 'Baur, 212 ff.'. Baur, Religionssystem (n. 47), 212-214 refers to Mani's Ep. fund. and to ch. 7 of the Acta Archelai, although the last mentioned text speaks of the Living Spirit who reaches the Right Hand to the First Man. Baur, however, rightly remarks: 'Es ist hier zunächst nicht Christus, sondern das $\zeta \omega \nu \pi v \varepsilon v \mu \alpha$, oder der demiurgische Geist, genannt, aber es ist auch schon gezeigt worden, daß zwischen beiden eine sehr nahe Beziehung angenommen werden muß: was der Eine begonnen, wird im Grunde von dem Anderen nur vollendet, der Eine wie der Andere ist errettend aus dem Dunkel, befreiend 
passage in the Chinese Traité, published for the first time in 1911 by the French scholars Éduard Chavannes and Paul Pelliot, ${ }^{64}$ which runs as follows in their German translation:

Der große Heilige [sc. Jesus] ist

... die aus dem feurigen Pfuhl mitleidig rettende Hand. ${ }^{65}$

In addition, Waldschmidt and Lentz mention another important text, a hymn transmitted both in Persian ${ }^{66}$ and Sogdian, with the heading (in Sogdian):

'Angefangen hat das Preislied des Königs Jesu: Voll wollen wir machen'. ${ }^{67}$ Here it runs in the Persian version with reference to Jesus:

Gekommen bist du mit Heil, unsere uranfängliche Rechte und unser Lebensäther ... ${ }^{68}$

'Uranfänglich' here means that Jesus is 'primaeval' like the Father, a Manichaean view that coincides with the confession of Fortunatus in his disputation with Augustine. ${ }^{69}$

Another Manichaean text in Persian, classified in scientific source editions as M 36, speaks of Jesus as 'the Right Hand of Salvation'. In the translation of the first editors, Friedrich Carl Andreas and Walter Henning, it runs as follows in this hymn for the Manichaean hierarchy and the community:

Gesegnet sei, ${ }^{70}$ auf daß sich vollenden zur Vollkommenheit die Schwestern, die heiligen(den) Mädchen, die Bräute des lichten Bräutigams; mögen sie geschützt werden durch die Rechte des Heils und in das Reich der Lebendigen gelangen. ${ }^{71}$

und erlösend. Der Ausdruck dextera luminis bezeichnet ferner Christus zugleich als reines Lichtwesen'. See further below.

${ }^{64}$ É. Chavannes \& P. Pelliot, 'Un Traité manichéen retrouvé en Chine', Journal Asiatique $10^{\text {e }}$ série, XVIII (1911) 499-617; JA 11 série, I (1913) 99-199; 261-394.

${ }^{65}$ Waldschmidt \& Lentz, Stellung Jesu, 124-125; cf. 40. Cf. Chavannes-Pelliot, 'Traité', 586: 'il est aussi la main secourable et compatissante dans les gouffres de feu'.

${ }^{66} \mathrm{Cf}$. Waldschmidt \& Lentz, Stellung Jesu, 70: 'Norddialekt' and 128: 'ND = iranischer Nord (west)dialekt $=$ Reichssprache der Arsakiden'.

${ }^{67}$ Waldschmidt \& Lentz, Stellung Jesu, 70 and 90.

${ }^{68}$ Waldschmidt \& Lentz, Stellung Jesu, 95.

${ }^{69}$ Augustine, c. Fort. 3 (CSEL 25,85): 'sui similem [sc. to the eternal Father of Light] saluatorem direxisse ...'?

${ }^{70}$ Sic.

${ }^{71}$ F.C. Andreas \& W. Henning, 'Mitteliranische Manichaica aus Chinesisch-Turkestan', II, SPAW PH 1933, Berlin: Verlag der Akademie der Wissenschaften in Kommission bei Walter de Gruyter 1933, 294-363 (325-326). In H.-J. Klimkeit, Gnosis on the Silk Road. Gnostic Texts from Central Asia, New York: Harper SanFrancisco 1992, 93 it reads: 'Blessed be the sisters, the holy virgins, the brides of the Bridegroom of Light (Jesus). May the right hand of salvation adorn them, and may they enter into the Realm of the Living', following his German version in 
Based upon New Testament imagery, ${ }^{72}$ Jesus is here depicted as the 'Bridegroom of Light' of the Manichaean virgins. He also is, once again, the Right Hand of Salvation who protects. It may be noted that in the same Middle Iranian fragment M 36, as sometimes elsewhere, ${ }^{73}$ the Manichaean Elect are called 'the sons of the Right Hand'. ${ }^{74}$

The Eastern texts also abound in their depiction of Jesus as the Physician. ${ }^{75}$ Out of the many testimonies, only the following two may be quoted:

Aller Kranken großer Heilkönig!

Aller Dunklen großes Licht!

Aller, die (in die) vier (Richtungen) zerstreut ${ }^{76}$ sind, hilfreiche Sammlung! $!^{77}$

il [sc. Jesus] est aussi le grand médecin pour les êtres qui ont en eux une âme. ${ }^{78}$

The last quote comes from the final hymn in the Chinese Traité, which song is one grand eulogy of Jesus. ${ }^{79}$ In this eulogy, Jesus is—as we have seen-also praised as 'la main secourable et compatissante'. ${ }^{0}$

Klimkeit, Hymnen und Gebete des Lichts, Opladen: Westdeutscher Verlag 1989, 134: 'Gesegnet seien, auf daß sie sich vollenden zur Vollkommenheit (ispurrgärïh), die Schwestern, die heiligen Jungfrauen, die Bräute des Licht-Bräutigams (= Jesus). Mögen sie geschmückt werden durch die Rechte des Heils (drōdīh) und in das Reich der Lebendigen gelangen'.

${ }^{72}$ Cf. Mt. 9:15; 25,1-13; John 3:29.

${ }^{73}$ According to the Muslim writer al-Murtadā, already in Mani's Shäbuhragan (cf. K. Kessler, Mani. Forschungen über die manichäische Religion, Berlin: Georg Reimer 1889, 349 and 355, although his translation has been called in question); in any case in the other Turfan fragments M 4 and M 801; cf. Puech, Sur le manichéisme, 372.

${ }^{74}$ Andreas \& Henning, 'Mitteliranische Manichaica', II, 326; cf. Klimkeit, Gnosis on the Silk Road, 93.

${ }^{75}$ Cf. Waldschmidt \& Lentz, Stellung Jesu, 37: 'Besonders häufig ist die Bezeichnung Jesu als « Arzt »', with references to several instances in the Hymnscroll. Cf. e.g. Andreas \& Henning, 'Mitteliranische Manichaica', II in their translation of M 28 II (313: 'Du bist ... ein [edler] Artz'; 'Arzt der Verwundeten'; 317: 'neuer Arzt!').

${ }^{76}$ Cf. e.g. Hymnscroll 52, c-d.

${ }^{77}$ Hymnscroll 36 a-c, according to Waldschmidt \& Lentz, Stellung Jesu, 103.

${ }^{78}$ Chavannes-Pelliot, 'Traité', 586.

${ }^{79}$ In this interpretation, I follow Waldschmidt \& Lentz, Stellung Jesu, 37, although it is clear that at the beginning of the Traité as we have it (Chavannes \& Pelliot, 509) the 'Envoyé de la lumière' is Mani. Anyhow, as has been indicated above, it is functions of Jesus which have been attributed to Mani.

${ }^{80}$ Cf. above, n. 65.-Other texts which might be of particular interest in this context are one of Mani's Psalms (see D. Durkin-Meisterernst \& E. Morano, Mani's Psalms. Middle Persians, Parthian and Sogdian Texts in the Turfan Collection, Turnhout: Brepols 2010, 209: ' ... and in/through you(r) ... [by] (the application of) your [= God's] right hand peace ... ...' and a passage from T II D 78b, i.e. a Prayer to Azruwā [= God] in L. Clark, Uygur Manichaean Texts: Texts, Translation, 


\section{B. Testimonies from Manichaean Art?}

The testimonies from the various documents quoted above provide ample proof that the Manichaeans considered Jesus to be God's (Right) Hand. At the same time, they show Jesus in his pivotal functions as human beings' Rescuer, Protector and-not least - their Physician. Texts from East and West coincide in all these aspects, which is no wonder since Mani's worldwide Church—although with notable differences in regional expressions - was based upon the prophet's canonical set of scriptures and thus constituted a (in essence static) GnosticChristian book religion. In view of this fact it might be expected that the imagery of God's Hand also formed part of its impressive art legacy.

Over the past years, Zsuzsanna Gulácsi has unlocked the most important expressions of Manichaean art to a wider circle of scholars. In a considerable number of books and articles, she discusses the remnants of Manichaean art discovered in the Turfan region since the beginning of the previous century and recently in Eastern China and Japan. Among the corpus of Manichaean art expressions, one in particular appears to be important in this context. As far as I can see, it may deal with Christ as God's (Right) Hand.

The picture in question belongs to the collection of the Asian Art Museum (formerly: Museum für Indische Kunst) in Berlin and is catalogued as MIK III 4974 recto. It was painted on paper as a book miniature sometime in the tenth century; its small scale is reported to be $6.6 \mathrm{~cm}$ in height and $6.1 \mathrm{~cm}$ in width. Although discussed in a number of publications since its discovery at an unspecified site in Kocho in the Turfan region, ${ }^{81}$ its meaning seems to have become clear only recently. It has been described by Gulácsi as the 'Work of Religion Scene' and recently as 'the Salvation of the Light and/with God's Hand, ${ }^{22}$ i.e., a depiction of how the Manichaean religion works in its essential

Commentary, Volume II: Liturgical Texts, Turnhout: Brepols 2013, 288: 'Deign to cleanse my stains! Now, with your [=God's] right hand that is merciful, deign to [ ] a good reward!' However, the fragmentary status of both texts does not allow for clear conclusions.

${ }^{81}$ E.g. A. von Le Coq, Die buddhistischen Spätantike, II, Die manichäischen Miniaturen, Berlin: Dietrich Reimer 1923 (repr. Graz: Akademische Druck- und Verlagsanstalt 1973), 45-46 + Tafel 7a; H.-J. Klimkeit, Manichaean Art and Calligraphy, Leiden: Brill 1982, 39.

${ }^{82}$ Zs. Gulácsi, Manichaean Art in Berlin Collections, Turnhout: Brepols 2001, 83-86; eadem, 'Reconstructing Manichaean Book Paintings through the Technique of Their Makers: The Case of The Work of Religion Scene on MIK III 4974 recto', in: P. Mirecki \& J. BeDuhn (eds.), The Light and the Darkness. Studies in Manichaeism and its World, Leiden-Boston-Köln: Brill 2001, 105-127; eadem, Mediaeval Manichaean Book. Art, Leiden-Boston: Brill 2005, e.g. 211-213; eadem, 'An Experiment in Digital Reconstruction with a Manichaean Book Painting: The Work of the Religion Scene (MIK III 4974 recto)', in: J.D. BeDuhn (ed.), New Light on Manichaeism, Leiden-Boston 2009, 145-168 (+ 1 Plate and 10 Figures); eadem, Mani's Pictures. The Didactic Images of the Manichaeans from Sassanian Mesopotamia to 
function of liberating the Light elements dispersed in matter. On the miniature, one sees in the centre's lower part a bowl with figs (a species of fruit considered to be full of Light particles), which is offered by two lay people to two Elect (a younger man and an older, bearded man). The miniature captures how the Elect are supposed to consume the fruit, after which their bodies function as the media by which the liberation of Light takes place. This saved Light is supposed to be forwarded to the heavenly bodies depicted at the upper right side of the scene. Above these heavenly bodies (i.e., a waxing moon crescent, a sun disk, and eight smaller disks of stars ${ }^{83}$ ) a big Hand reaches into the picture, symbolizing a divine act.

I deliberately provide a general description of the picture, because in some aspects I see reasons to differ from Gulácsi's more detailed accounts. What we are mainly concerned with here is the depiction and role of the heavenly Hand. This Hand is painted partly outside the frame formed by the blue background on which the described figures (bowl with fruit; auditores; electi; heavenly bodies) are portrayed. Gulácsi rightly remarks that the Hand's gesture mirrors the main Elect's raised left hand, i.e., the thumb and index finger of the divine Right Hand are touching, which corresponds with the gesture of the senior Elect's hand. ${ }^{84}$ All this symbolizes the human offering, heavenly release, and divine acceptance of the Light.

Gulácsi defines the Hand as being 'God's Hand'. Although not specifically argued, her reference point on the subject turns out to be the well-known pictures of the divine Hand from the Dura Europos synagogue. ${ }^{85}$ At first sight, one may

\footnotetext{
Uygur Central Asia and Tang-Min China, Leiden-Boston: Brill 2015, e.g. 283 'the Salvation of the Light with God's Hand'; 285-287 ('the Salvation of the Light and God's Hand'; 'Salvation of the Light'; 'the Salvation of the Light with God's Hand'); 317 ('Salvation of the Light and God's Hand'); 320-321; 322 ('Salvation of the Light and God's Hand').

${ }^{83}$ According to the most detailed description in Gulácsi, 'Digital Reconstruction with a Manichaean Book Painting', 162.

${ }^{84}$ E.g. Gulácsi, 'Reconstructing Manichaean Book Paintings', 121; 'Digital Reconstruction with a Manichaean Book Painting', 163.

${ }^{85}$ In Manichaean Art, 86 as well as in 'Digital Reconstruction' 147 and 163-164, she gives no references, but simply states that the hand reaching into the picture represents God's Hand. In 'Reconstructing Manichaean Book Paintings', 124, she states: 'The Manichaean application of the motif of God's hand is analogous to that seen in early Jewish and Christian art, for example on the wall paintings in the synagogue at Dura Europos'. In her main analysis in Mani's Pictures, 320-331, she always terms the hand to be 'God's hand' and additionally remarks: 'as also seen at the synagogue at Dura' (320) and further: 'Its [sc. the book painting's] dominant motifs (God's right hand, and moon and sun) are attested at Roman Dura-Europos from the middle of the third century - from about the same time when Mani assembled the collection of his didactic paintings in Sassanian Mesopotamia' (331). Cf. ibidem, 287 n. 123.
} 
agree with this representation. ${ }^{86}$ A curious detail of the miniature, however, may not be overlooked: the Hand is portrayed with the wrist and part of the lower arm dressed in a red sleeve. ${ }^{87}$ In Manichaean art-as also elsewhere- the robe of Christ was often red. ${ }^{88}$ Both in light of this feature, and particularly in light of the Manichaean texts discussed above, I venture to suppose that we may see here a representation of Christ as God's Right Hand, a point Gulácsi does not mention, possibly because she misrepresented Augustine's quote from Mani's ep. fund. ${ }^{89}$ by supposing that 'the right hand of the Light' is merely an 'evocation of God'. ${ }^{90}$

Perhaps it is also important that, on the original manuscript page, the miniature under discussion is not only surrounded by a benediction on the sacred meal and the leadership of the Manichaean community, ${ }^{11}$ but also accompanied by two marginal decoration figures which mirror each other. Whether these naked boys or putti in red contour drawing here (also) represent the Manichaean Christ could be a matter of future discussion. ${ }^{92}$

The several other instances of the symbol of the right hand in Manichaean $\operatorname{art}^{93}$ and also the typical representation of Jesus' Right Hand ${ }^{94}$ may remain topics of future discussion as well. In recent years, Gulácsi and others ${ }^{95}$ have brought to light more than a few examples, and the scholarly discussions of these are still in its formative phase.

${ }^{86}$ See e.g. K. Weitzmann \& H.L. Kessler, The Frescoes of the Dura Synagogue and Christian Art, Washington: Dumbarton Oaks 1990, Figs. 152 \& 177-179 (cf. Gulácsi, 'Reconstructing', 124 n. 29).

${ }^{87}$ Cf. e.g. Gulácsi, 'Digital Reconstruction', 163; Mani’s Pictures, 330 (coloured detail of digital reconstruction).

${ }^{88}$ See e.g. the three Uygur 'Icons of Jesus' reproduced in Gulácsi, 274-275 and further discussed on e.g. p. 416, 419, 420. For mainstream Christian art depicting Christ in a red robe, see e.g. the $4^{\text {th }}$ c. apse mosaics in the church of Santa Pudenziana in Rome (cf. Zs. Gulácsi, 'A Manichaean Portrait of the Buddha Jesus. Identifying a Twelfth-Thirteenth-century Chinese Painting from the Collection of Seiun-ji Zen Temple', Artibus Asiae 69 (2009) 91-145, esp. 136-137).

${ }^{89}$ See above, the beginning of section 'A.: Testimonies from Manichaean Literature: 1. Latin Testimonies, i. Mani’s Epistula fundamenti’

${ }^{90}$ Gulácsi, Mani's Pictures, 327-328.

${ }^{91}$ English translation of the Middle Persian text in Manichaean script by J. BeDuhn in Gulácsi, Manichaean Art, 228-230.

${ }^{92}$ Cf. e.g. V. Arnold-Döben, Die Bildersprache des Manichäismus, Köln: In Kommission bei E.J. Brill 1978, 115 as well as Rose, Christologie, 103-109 on the Manichaean 'Youth'.

${ }^{93}$ See e.g. Gulácsi, Mani's Pictures, 146; 264-265; 342; 431; 434; 468.

${ }^{94}$ See e.g. Gulácsi, Mani's Pictures, 274; 277; 417-421; 424-425; 427; 468.

${ }^{95}$ Such as, for instance, the Japanese scholars Yutaka Yoshida and Takao Moriyasu. See e.g. Moriyasu, 'The Discovery of Manichaean Paintings in Japan and their Historical Background', in: J.A. van den Berg a.o. (eds.), In Search of Truth: Augustine, Manichaeism and Other Gnosticism. Studies for Johannes van Oort at Sixty, Leiden-Boston: Brill 2011 (repr. 2017), 339-369; cf. Gulácsi, 'The Central Asian Roots of a Chinese Manichaean Silk Painting in the Collection of the Yamato Bunkanan, Japan', ibidem, 315-337. 


\section{Conclusion}

From the above overview of testimonies from Manichaean texts, it may be concluded that

- Manichaean texts frequently speak of the 'Right Hand' in an emphatic way;

— in all cases, this Hand turns out to be a metaphor for Christ;

- again and again, this '(Right) Hand' is characterized by its rescuing, protecting and healing function.

Already Mani himself spoke of Christ as 'the Right Hand of the Light'. A close reading of other Manichaean texts reveals that, time and again, it is the divine Jesus who stretches out his Right Hand. As Augustine already remarked, the 'trinitarian' concept of the Manichaeans is strongly 'modalistic', which entails that functions of the Father have been assigned to Christ. In light of the plethora of Manichaean texts speaking of the rescuing function of Christ as the Right Hand, I deem it possible to see the divine Right Hand on MIK 4974 as depicting Christ as well.

The interesting question of whether this metaphor is Mani's own invention or whether he learned about it in his own Syrian milieu may only briefly be touched upon here. Documents from this milieu such as the Odes of Solomon (which most likely date from the late second century CE) and the Acts of Thomas (which have strong affinities with Manichaeism and were apparently written before the middle of the third century) indeed contain the metaphor. ${ }^{96}$ This may indicate that Mani could have encountered this figure of speech-like, for instance, his depiction of Jesus as the Physician ${ }^{97}$ - in the Syrian Christian milieu of his youth.

\footnotetext{
${ }^{96}$ See Odes of Solomon 8,6; 14,4; 18,7; 19,5; 22,7; 25,2.9; 38,22. Cf. e.g. H.J.W. Drijvers, 'Odes of Solomon and Psalms of Mani', in: R. van den Broek \& M.J. Vermaseren (eds.), Studies in Gnosticism and Hellenistic Religions presented to Gilles Quispel ..., Leiden: E.J. Brill 1981, 117-130. Acts of Thomas 48; see e.g. A.F.J. Klijn, The Acts of Thomas. Introduction-Text-Commentary, Leiden: E.J. Brill 1962, 90 and 241-242; cf. Klijn, The Acts of Thomas. Introduction, Text, and Commentary. Second Revised Edition, Leiden-Boston: Brill 2003, 120-121.

${ }^{97}$ Cf. e.g. R. Murray, Symbols of Church and Kingdom. A Study in Early Syriac Tradition, Cambridge: CUP 1975, e.g. 199-203.
} 